\title{
Effects of L-Carnitine Treatment on Kidney Mitochondria and Macrophages in Mice with Diabetic Nephropathy
}

\author{
Seigo Ito $^{a}$ Masahiro Nakashima ${ }^{b}$ Takuya Ishikiriyama $^{b}$ Hiroyuki Nakashima $^{b}$ \\ Akira Yamagata $^{a}$ Toshihiko Imakiire $^{a}$ Manabu Kinoshita ${ }^{b}$ Shuhji Seki ${ }^{b}$ \\ Hiroo Kumagai $^{a} \quad$ Naoki Oshima ${ }^{a}$ \\ aDepartment of Nephrology and Endocrinology, National Defense Medical College, Tokorozawa, Japan; \\ ${ }^{b}$ Department of Immunology and Microbiology, National Defense Medical College, Tokorozawa, Japan
}

\section{Keywords}

Diabetic nephropathy - L-Carnitine · Mitochondria ·

Macrophage $\cdot$ Toll-like receptor $9 \cdot$ Tumor necrosis factor-a

\begin{abstract}
Introduction: In diabetic nephropathy (DN), mitochondrial dysfunction and leakage of mitochondrial DNA (mtDNA) are caused by the downregulation of superoxide dismutase 2 (SOD2). mtDNA induces the activation of Toll-like receptor (TLR) 9, which is present in macrophages (M $\varphi s$ ), and triggers their activation. Methods: We orally administered L-carnitine, which exerts protective effects on the mitochondria, to obesity-induced DN ( $\mathrm{db} / \mathrm{db})$ mice for 8 weeks. We then investigated the effects of L-carnitine on kidney mitochondrial reactive oxygen species (mtROS) production, circulating mtDNA content, and kidney CD $11 b^{\text {high }} / C D 11 b^{\text {low }} M \varphi$ functions. Results: In db/db mice, mtROS production increased in proximal tubular cells and kidney $C D 11 b^{\text {low }} M \varphi s$; both $M \varphi$ types showed enhanced TLR9 expression. L-Carnitine treatment suppressed mtROS production in both proximal tubular cells and CD11 b low M $\varphi s(p<0.01)$, with improved SOD2 expression in the kidney ( $p<0.01$ ), decreased circulating mtDNA content, and reduced albuminuria. Moreover, it sup-
\end{abstract}

pressed $M \varphi$ infiltration into kidneys and reduced TLR9 expression in $M \varphi s(p<0.01)$, thereby lowering tumor necrosis factor-a production in CD11 bigh $\mathrm{M} \varphi s(p<0.05)$ and ROS production by $\mathrm{CD} 11 \mathrm{~b}$ low $\mathrm{M} \varphi s(p<0.01)$. Collectively, these changes alleviated DN symptoms. Conclusion: The positive effects of L-carnitine on DN suggest its potential as a novel therapeutic agent against obesity-linked DN.

(c) 2022 The Author(s).

Published by S. Karger AG, Basel

\section{Introduction}

Diabetic nephropathy (DN) affects approximately $40 \%$ of patients with diabetes and is the major cause of chronic kidney disease worldwide $[1,2]$. End-stage kidney disease may be the most recognizable result of $\mathrm{DN}$; however, most patients actually die of cardiovascular disease and infection before kidney replacement therapy is performed [2]. In many cases, disease progression cannot be prevented by only controlling blood sugar or blood pressure to optimum levels. Therefore, to develop better therapeutics against DN, its molecular pathogenesis must be further elucidated.
(C) 2022 The Author(s)

Published by S. Karger AG, Basel

This is an Open Access article licensed under the Creative Commons Attribution-NonCommercial-4.0 International License (CC BY-NC) (http://www.karger.com/Services/OpenAccessLicense), applicable to the online version of the article only. Usage and distribution for commercial purposes requires written permission.
Correspondence to:

Seigo Ito, sitoh@ndmc.ac.jp 
Mitochondrial dysfunction is involved in DN pathogenesis $[3,4]$. This dysfunction is related to the downregulation of superoxide dismutase 2 (SOD2), which is localized in the mitochondria, and normally eliminates mitochondrial reactive oxygen species (mtROS) [5-8]. In an obesity mouse model fed with a high-fat diet, mitochondrial dysfunction enhanced mtROS production and damaged vascular endothelial cells, podocytes, and tubular cells via the inhibition of mitochondrial lipid $\beta$-oxidation and intracellular lipid accumulation [9]. These changes then cause proteinuria and interstitial inflammation.

In a septic mouse model, mitochondrial dysfunction increased circulating mitochondrial DNA (mtDNA) levels, which stimulated Toll-like receptor (TLR) 9 production in macrophages $(\mathrm{M} \varphi s)$ and exacerbated kidney injury through elevated inflammation [10]. Further, bacterial DNA with unmethylated CpG motifs has been shown to stimulate TLR9 action, which protects against bacterial infection through its involvement in tumor necrosis factor- $\alpha$ (TNF- $\alpha)$ production $[11,12]$. In metabolic syndromes and obesity (underlying conditions that increase diabetes risk), TLR9 activates innate immunity and induces inflammation by recognizing cell-free DNA released into circulation from dead cells or adipocytes [13]. Furthermore, dysfunction-generated mtROS stimulate $\mathrm{M} \varphi s$ and cause NF- $\kappa \mathrm{B}$-mediated inflammation [14].

Both $\mathrm{M} \varphi$-driven TNF- $\alpha$ and ROS are involved in DN pathogenesis [15-18]. In the kidney, the $\mathrm{M} \varphi$ population is primarily composed of the CD11b ${ }^{\text {low }} \mathrm{F} 4 / 80^{\text {high }}$ and the CD11 $b^{\text {high }} \mathrm{F} 4 / 80^{\text {low }}$ subsets $[19,20]$. In our earlier studies using metabolic-syndrome mouse models, we classified hepatic $\mathrm{M} \varphi s$ into two types: bone marrow-derived CD11b ${ }^{\text {high }} \mathrm{M} \varphi$ s with high TNF- $\alpha$ production capacity and tissue-resident CD $11 b^{\text {low }} \mathrm{M} \varphi$ s with ROS production capacity and phagocytic activity [21-25]. Enhancement of TNF- $\alpha$ and ROS production is associated with organ damage through chronic inflammation.

Currently, as a treatment for DN, angiotensin II receptor blocker and sodium glucose cotransporter 2 inhibitors have been used, in addition to optimizing blood glucose levels, to eliminate glomerular hyperfiltration. However, these agents do not have an adequate urinary protein reduction effect on advanced $\mathrm{DN}$, which is associated with an increased urinary protein level. Furthermore, no treatment directly ameliorates the mitochondrial abnormalities of the kidney and the resulting inflammation underlying the pathology of DN.

L-Carnitine acts as a fatty-acid carrier in the mitochondria, exerts protective effects on the mitochondria [26-
28], and restores SOD2 expression [29-32]. The compound is widely used for treating carnitine deficiency and erythropoiesis-stimulating factor-resistant anemia in dialysis patients. In addition, L-carnitine has been suggested to be effective for diabetes, diabetic peripheral neuropathy, and diabetic podocyte injury [33-35]; however, its efficacy through mitochondrial protection in $\mathrm{DN}$ has not been investigated.

In this study, we administered L-carnitine to an obese mouse model of type 2 diabetes $(\mathrm{db} / \mathrm{db}$ mice) and investigated whether the protective effect of L-carnitine on the mitochondria in proximal tubules and kidney $\mathrm{M} \varphi s$ would mitigate DN. Furthermore, we examined whether this protection influences the proportion and function of two $\mathrm{M} \varphi$ types in the kidneys. We, thus, aimed to investigate whether L-carnitine could alleviate DN by suppressing local kidney inflammation through kidney mitochondrial protection.

\section{Materials and Methods}

Animals

Male diabetic $\mathrm{db} / \mathrm{db}$ mice (8-20 weeks old; C57BLKS/J lar$+\operatorname{Lepr}^{d b} /+\operatorname{Lepr}^{d b}$ ) and their control nondiabetic littermates (misty; C57BLKS/J lar- $\mathrm{m}+/ \mathrm{m}+$ ) were purchased from CLEA (Tokyo, Japan). All mice were housed under controlled conditions with a 12-h light/dark cycle. Food and water were provided ad libitum.

\section{L-Carnitine Oral Administration}

The average water intake of $\mathrm{db} / \mathrm{db}$ mice was about $10 \mathrm{~mL} /$ day from 8 to 16 weeks of age. The daily dose of L-carnitine L-tartrate (hereafter, L-carnitine; FUJIFILM Wako Pure Chemical, Osaka, Japan) was $25 \mathrm{mg} /$ individual [36]. Therefore, $2.5 \mathrm{~g} / \mathrm{L}$ solution of $\mathrm{L}$-carnitine was prepared and administered in drinking water from 8 weeks to 16 weeks of age (LC group). This treatment age and period were selected because urinary albumin (Alb) excretion is apparent at 8 weeks of age and increases linearly up to 16 weeks of age in $\mathrm{db} / \mathrm{db}$ mice. Thus, the selected age and period were considered to appropriately reflect the exacerbation period of DN. The control (vehicle) group was administered regular water.

\section{Measurement of Metabolic Variables}

Urine samples were collected in metabolism cages, and urinary Alb levels were measured using the competitive enzyme-linked immunosorbent assay (ELISA) (Exocell, Philadelphia, PA, USA). Serum creatinine and plasma glucose levels were measured using an enzymatic method (SRL, Tokyo, Japan).

\section{Preparation of Kidney Single-Cell Suspension}

Mice were euthanized under deep anesthesia to obtain their left kidneys after saline perfusion. Kidneys were treated with collagenase for $40 \mathrm{~min}$ at $37^{\circ} \mathrm{C}$, filtered through a stainless-steel mesh, and dissolved. Dissociated kidney cells were resuspended in an isotonic 30\% Percoll solution (Sigma, St. Louis, MO, USA), layered on an isotonic $60 \%$ Percoll solution, and centrifuged at $430 \mathrm{~g}$ for $30 \mathrm{~min}$. 
The layer between the two Percoll solutions is rich in mononuclear cells (MNCs). This was collected, resuspended in red blood cell lysis solution, and filtered through a $40-\mu \mathrm{m}$ polypropylene cell strainer. These methods are a modification of established protocols for collecting liver MNCs [37].

\section{Flow Cytometry}

Kidney MNCs were incubated with Fc-blocker (2.4 G2; BD Biosciences, Franklin Lakes, NJ, USA) to prevent nonspecific binding. For the identification of $\mathrm{M} \varphi s$, kidney MNCs were stained with allophycocyanin-labeled anti-CD45 (30-F11; eBioscience, San Diego, CA, USA), FITC- or phycoerythrin (PE)-labeled antiF4/80 (BM8; eBioscience), and PE-Cyanine5-labeled anti-CD11b (M1/70; eBioscience) antibodies. To measure $\mathrm{M} \varphi$-infiltration of kidneys, samples were further stained with PE-labeled anti-Ly6G antibody (clone: 1A8-Ly6g; eBioscience) to exclude neutrophils that highly express Ly6G. Samples were then stained with PE-labeled TLR9 (J15A7; BD Biosciences) antibodies to identify TLR9 expression in M $\varphi s$. Immediately before incubation with TLR9 antibodies, cell suspensions were subjected to cell membrane permeabilization using a BD Cytofix/Cytoperm ${ }^{\mathrm{TM}}$ Fixation/Permeabilization Kit (BD Biosciences). For proximal tubular cell identification, the cell suspension was incubated at $4^{\circ} \mathrm{C}$ for $15 \mathrm{~min}$ along with nonspecific Fc-blocker (clone: $2.4 \mathrm{G} 2$; BD Biosciences), allophycocyanin-labeled anti-CD45 antibody (clone: 30-F11; eBioscience), and Lotus tetragonolobus lectin (LTL; Vector Laboratories, Burlingame, CA, USA), a marker of proximal tubular cells [38]. Fluorescence-activated cell sorting identified a CD45-negative cell group as containing nonleukocyte cells. Among them, LTL-positive cells were identified as proximal tubular cells. A sample without LTL was also analyzed to eliminate cellular autofluorescence.

Fluorescent MitoSOX ${ }^{\mathrm{TM}}$ red mitochondrial superoxide indicator (Thermo Fisher Scientific, Waltham, MA, USA) was added to kidney cell suspensions and incubated at $37^{\circ} \mathrm{C}$ for $10 \mathrm{~min}$. Mitochondria-derived ROS production in the cell population was evaluated as the ratio of MitoSOX fluorescence-positive cells to total cells. Cell-specific autofluorescence was excluded by comparing a sample and a control without MitoSOX. This allowed the identification of MitoSOX fluorescence-positive cells.

Samples were then analyzed using a NovoCyte Flow Cytometer (ACEA Biosciences, Inc., San Diego, CA, USA). Isotype control antibodies corresponding to each fluorescently labeled antibody were used as needed. The gating strategy is shown in online supplementary Figure 1 (for all online suppl. material, see www.karger. $\mathrm{com} / \mathrm{doi} / 10.1159 / 000522013)$. The $\mathrm{M} \varphi$-containing cell population was gated based on forward and side scatter, excluding neutrophils. However, considering that the gated cells contained kidney parenchymal cells (e.g., tubular cells), which must be excluded from $\mathrm{M} \varphi$ analysis, we gated lymphocytes and $\mathrm{M} \varphi$-containing cells using the general leukocyte marker CD45. Next, we identified, among CD $45^{+}$cells, F4/80 ${ }^{\text {low }} \mathrm{CD} 11 \mathrm{~b}^{\text {high }}$ cells (CD $\left.11 \mathrm{~b}^{\text {high }} \mathrm{M} \varphi \mathrm{s}\right)$ and $\mathrm{F} 4 / 80^{\text {high }} \mathrm{CD} 11 \mathrm{~b}^{\text {low }}$ cells (CD $11 \mathrm{~b}^{\text {low }} \mathrm{M} \varphi \mathrm{s}$ ), along with lymphocytes. We also identified proximal tubular cells as LTL-positive among CD $45^{-}$cells. We then determined the proportion of mitochondrial-ROS-producing $\left(\mathrm{mtROS}^{+}\right)$cells in each cell population.

\section{Evaluation of SOD2 Expression in Kidney Tissue}

Immunohistochemistry with THE anti-SOD2 antibody was used to assess SOD2 expression in the kidneys, with emphasis on the tubules. Paraffin-embedded tissue sections were deparaffinized, hydrophilized, and antigen-activated with a citrate buffer solution $(\mathrm{pH} 6)$ at $98^{\circ} \mathrm{C}$ for $1 \mathrm{~h}$. After inhibition of nonspecific binding, tissue samples were incubated at $4^{\circ} \mathrm{C}$ for $24 \mathrm{~h}$ with a rabbit-derived, anti-SOD2, polyclonal primary antibody (ab13534; Abcam, Cambridge, UK), diluted 1,000-fold. Next, endogenous peroxidase in the tissue was inhibited, and samples were incubated with secondary antibody Histofine Simple Stain Mouse MAX PO (R) (Nichirei, Tokyo, Japan) at $20-24^{\circ} \mathrm{C}$ for $40 \mathrm{~min}$ and stained with diaminobenzidine. Nuclei were stained with Mayer's hematoxylin, and sections were mounted after dehydration and clearing. In each section, four fields of view were photographed randomly under $\times 20$ magnification. Using ImageJ-Fiji, SOD2-positive regions were extracted, and the positive area ratio was calculated [39].

\section{Electron Microscopic Analysis}

For electron microscopy, samples were fixed in $4 \%$ paraformaldehyde containing $0.25 \%$ glutaraldehyde. Ultrathin sections obtained from embedded Epon blocks were stained with uranyl acetate and lead citrate and examined using an electron microscope.

\section{mtDNA Measurement}

Total genomic DNA was extracted from the serum using the QIAamp DNA Blood Mini Kit (Qiagen, Hilden, Germany), and mtDNA content was quantified by TaqMan real-time PCR using a StepOnePlus Real-Time PCR System (Applied Biosystems) and mouse cytochrome b primers (Mm04225271; Thermo Fisher Scientific) [10]. The mouse ribosomal protein large P0 (Rplp0) primer (Mm00725448; Thermo Fisher Scientific) was used as a nuclear genome control to normalize the cytochrome b level [40-42]. Fold changes in gene expression were calculated using the $2^{-\Delta \Delta C T}$ method [43].

\section{Evaluation of $M \varphi$ Function}

To assess TLR9-induced TNF- $\alpha$ production in M $\varphi s$, kidney cells rich in $\mathrm{M} \varphi$ s were re-stimulated in vitro with $20 \mathrm{ng} / \mathrm{mL} \mathrm{CpG-}$ ODN (HC4033: TCCATGACGTTCCTGATGCT; Hycult Biotechnology, Uden, The Netherlands) for $4 \mathrm{~h}$; monensin (BD Biosciences) was used to block cytokine release. Cells were collected and stained to check for the surface expression of CD45, F4/80, and CD11b after incubation with Fc-blocker. Permeabilization was performed using a Fixation/Permeabilization Solution Kit (BD Biosciences), and cells were stained with fluorescein isothiocyanate (FITC)-labeled anti-TNF- $\alpha$ antibody (MP6-XT22; eBioscience).

To measure ROS production, kidney cells were incubated with the Fc OxyBURST ${ }^{\mathrm{TM}}$ Green Assay Reagent (Thermo Fisher Scientific) at $37^{\circ} \mathrm{C}$ for $30 \mathrm{~min}$. The amount of ROS is expressed as a percentage of $\mathrm{M} \varphi s$ with positive fluorescence. Unstained cells were used to control for cell autofluorescence.

To assess phagocytic activity, kidney cells were incubated with FITC-labeled $0.75-\mu \mathrm{m}$ beads (Fluoresbrite YG Microspheres; Polysciences, Warrington, PA, USA) at $37^{\circ} \mathrm{C}$ for $30 \mathrm{~min}$. Activity is expressed as a percentage of $\mathrm{M} \varphi$-containing FITC beads.

\section{Determination of Kidney TNF- $\alpha$ Levels}

Proteins were extracted from kidney tissues using cell lysis buffer (radioimmunoprecipitation buffer; Wako) containing a $1 \%$ protease inhibitor cocktail (Nacalai Tesque, Kyoto, Japan) and subjected to an ELISA (TNF- $\alpha$ Mouse ELISA Kit; Thermo Fisher Scientific). Protein concentrations were determined using BCA 
Fig. 1. Effects of L-carnitine on $\mathrm{mtROS}^{+}$ and mitochondria of proximal tubular cells. Percentage of $\mathrm{mtROS}^{+}$cells in kidney CD11b ${ }^{\text {high }} \mathrm{M} \varphi s$ (a), CD $11 b^{\text {low }} \mathrm{M} \varphi s$ (b) ( $=8,4,10$, and 12 , respectively), and proximal tubular cells in the vehicle and the LC group of misty and $\mathrm{db} / \mathrm{db}$ mice $(\mathbf{c})(n=4$, 4,6 , and 8 , respectively). Data are presented as means \pm standard errors. Comparison between groups was performed using one-way analysis of variance with Tukey's HSD post hoc test. ${ }^{*} p<0.05,{ }^{* *} p<0.01$. Electron micrographs $(\times 3,000)$ of proximal tubules in the $\mathrm{db} / \mathrm{db}$-vehicle (d) and the $\mathrm{db} /$ db-LC mice (e). (a)

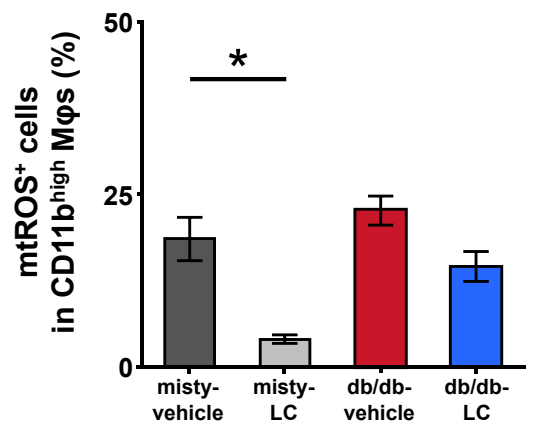

(b)

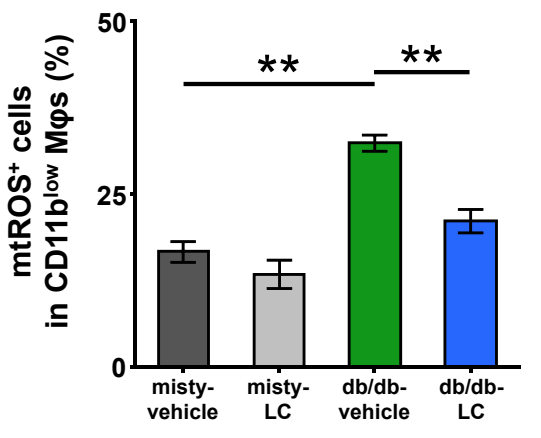

(c)

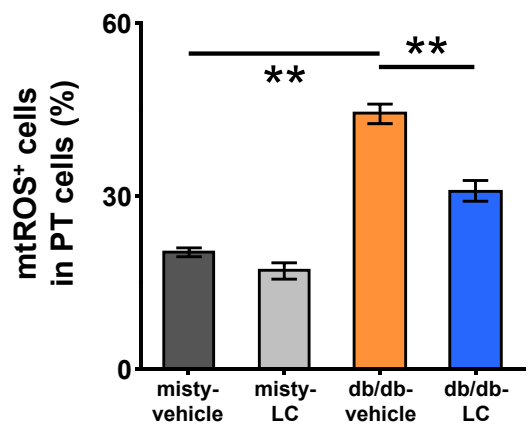

(d)

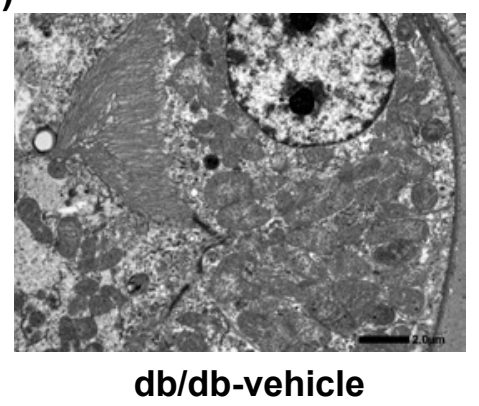

(e)

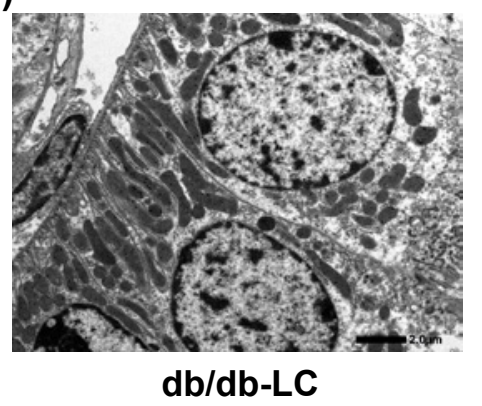

protein assay kits (Pierce; Thermo Fisher Scientific), and kidney TNF- $\alpha$ levels were evaluated per gram protein.

\section{Histological Analysis}

After removing kidney capsules, half of the right kidney was fixed in $4 \%$ paraformaldehyde solution for 1-2 days. Tissues were then embedded in paraffin for periodic acid-Schiff (PAS) and Masson trichrome staining, as well as podocyte quantification. Nuclei were counterstained with hematoxylin. Glomeruli PAS-stained sections were examined at $\times 400$ by blinded observers. Glomerular mesangial expansion was scored semiquantitatively, with the percentage of mesangial matrix per glomerulus rated on a five-point scale as follows: grade 0 , normal glomeruli; grade 1 , mesangial expansion area up to $25 \%$; grade $2,25-50 \%$; grade $3,50-75 \%$; and grade 4, >75\% [16, 44, 45]. In Masson trichrome-stained sections, four nonoverlapping low-power fields were randomly captured for analyzing the fibrotic area using ImageJ-Fiji [39].

Podocytes in paraffin-embedded sections were quantified after identification with Wilms tumor-I (WT-1) antibody (Santa Cruz Biotechnology, Dallas, TX, USA). Blinded observers counted WT$1^{+}$cells in 10-20 glomeruli per section under $\times 40$ magnification. Cell counts were averaged as described previously [46].

\section{Statistical Analysis}

Data are presented as means \pm standard errors. Nonparametric Mann-Whitney U tests were performed to compare two groups, and one-way analysis of variance with Tukey's HSD post hoc test was performed to compare three or more groups. All statistical analyses were performed in JMP version 14 (SAS Institute Inc., Cary, NC, USA). Statistical significance was set at $p<0.05$. 
(a)

\section{misty-vehicle}

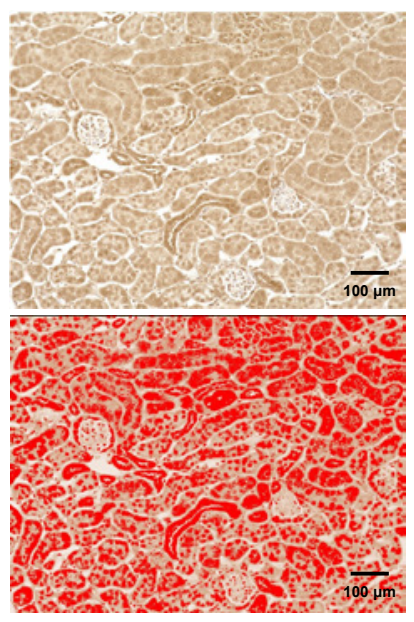

db/db-vehicle

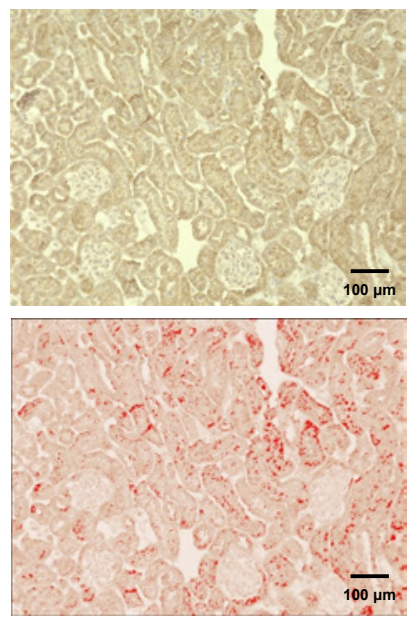

(b)
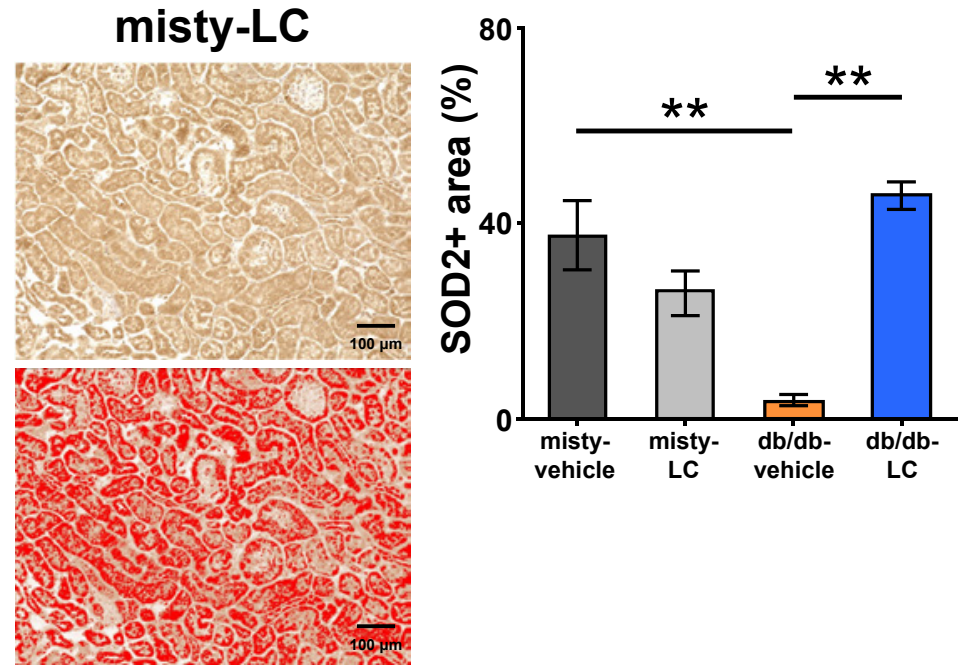

Fig. 2. Effect of L-carnitine on kidney SOD2 expression. a Kidney immunoperoxidase staining for SOD 2 at $\times 20$ magnification in misty-vehicle, misty-LC, db/db-vehicle, and $\mathrm{db} / \mathrm{db}-\mathrm{LC}$ groups (upper panels). SOD2 ${ }^{+}$areas viewed in ImageJ-Fiji (lower panels). b Percentage of SOD2 ${ }^{+}$areas in the misty-vehicle, the misty-LC, the db/ $\mathrm{db}$-vehicle, and the $\mathrm{db} / \mathrm{db}$-LC mice ( $n=4,4,8$, and 8 , respectively). Data are presented as means \pm standard errors. Comparison between groups was performed using one-way analysis of variance with Tukey's HSD post hoc test. ${ }^{* *} p<0.01$.

\section{Results}

\section{Effects of L-Carnitine Treatment on Mitochondrial}

ROS in Kidney M $\varphi$ s and on Mitochondria in Proximal Tubular Cells

Misty-vehicle and $\mathrm{db} / \mathrm{db}$-vehicle mice did not exhibit differences in percentages of $\mathrm{mtROS}^{+}$cells in kidney
CD11b ${ }^{\text {high }}$ M $\varphi s$ (Fig. 1a). However, db/db-vehicle mice had significantly higher percentages of $\mathrm{mtROS}^{+}$cells in kidney $\mathrm{CD} 11 \mathrm{~b}^{\text {low }} \mathrm{M} \varphi$ s than in misty-vehicle mice $(p<$ 0.01 ). L-Carnitine administration significantly lowered the $\mathrm{mtROS}^{+}$cell percentage in $\mathrm{CD} 11 \mathrm{~b}^{\text {low }} \mathrm{M} \varphi$ s among $\mathrm{db} /$ $\mathrm{db}$ mice ( $p<0.01$; Fig. 1b). Moreover, db/db-vehicle mice had a significantly higher percentage of $\mathrm{mtROS}^{+}$cells in 


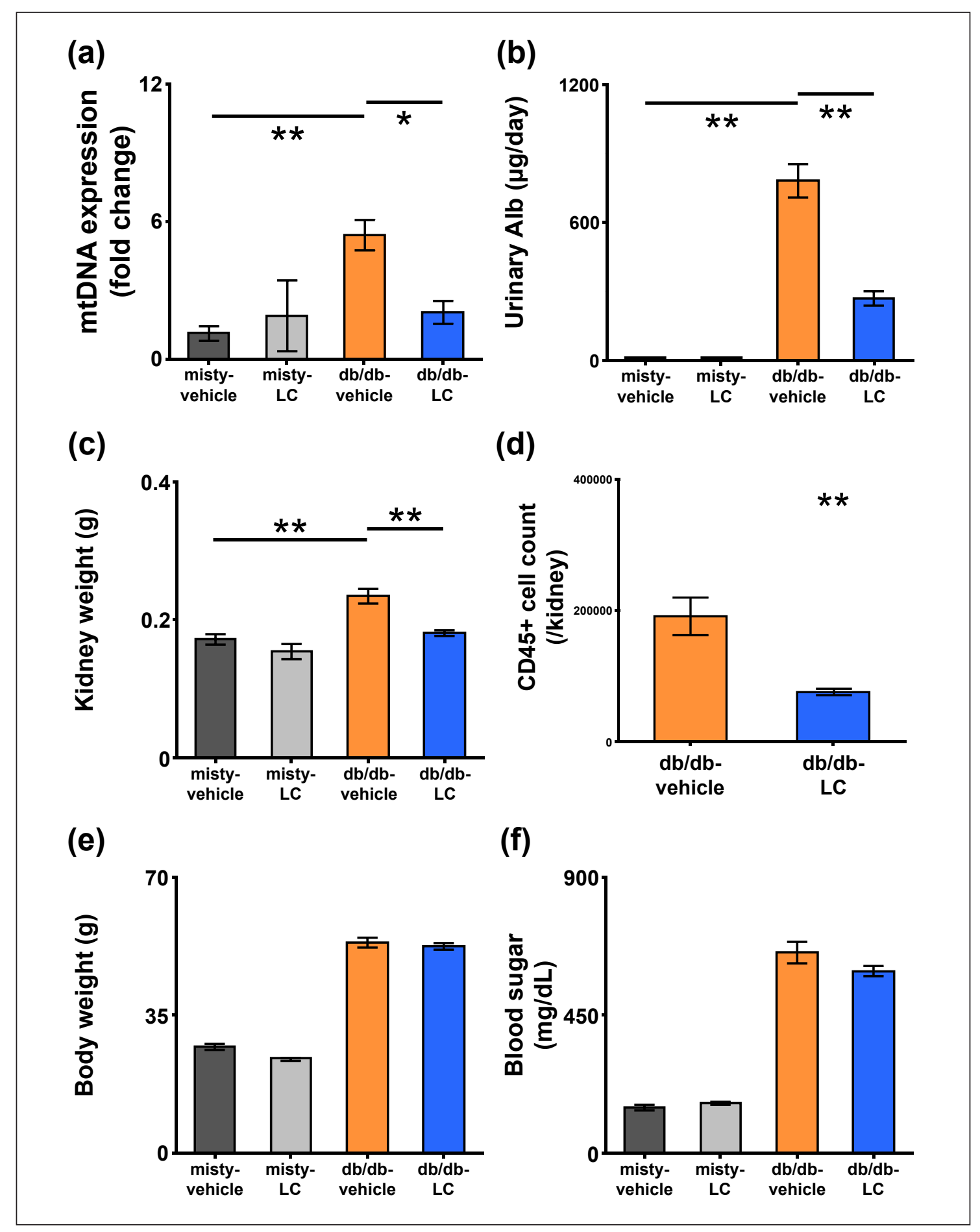

Fig. 3. Effects of L-carnitine on serum mtDNA and physiological parameters of DN. a mtDNA content was measured as the mitochondrial $(C y t B)$ to nuclear $(R p l p 0)$ DNA ratio by qRT-PCR in the vehicle and the LC groups of misty and $\mathrm{db} / \mathrm{db}$ mice $(n=4,4,12$, and 6, respectively). Urinary Alb excretion (b), kidney weight (c), body weight (e), and blood sugar levels (f) were measured in the vehicle and the LC groups of misty and $\mathrm{db} / \mathrm{db}$ mice $(n=4,8,8$, and 12 , respectively). Data are presented as means \pm standard errors.
Comparison between groups was performed using one-way analysis of variance with Tukey's HSD post hoc test. ${ }^{*} p<0.05,{ }^{* *} p<0.01$. d Number of leukocytes (CD45+ cells) infiltrating kidneys compared between the $\mathrm{db} / \mathrm{db}$-vehicle and the $\mathrm{db} / \mathrm{db}$-LC mice $(n=8$ and 12, respectively). Comparisons were conducted using the nonparametric Mann-Whitney $\mathrm{U}$ test. ${ }^{* *} p<0.01$ versus the $\mathrm{db} / \mathrm{db}$ vehicle mice. $C y t B$, cytochrome b; Rplp0, mouse ribosomal protein large P0. 
(a)
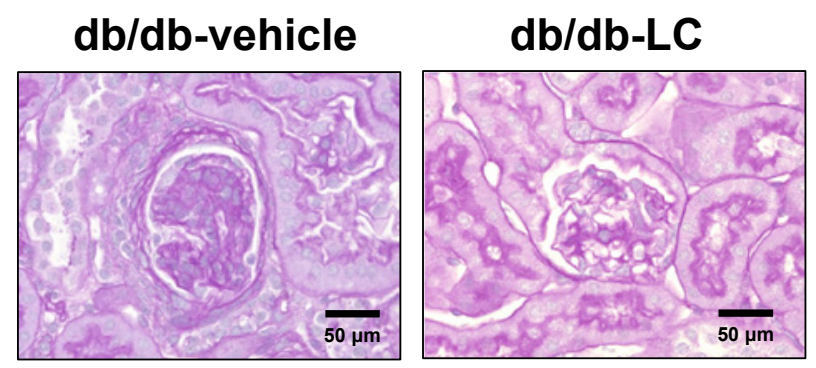

(c)
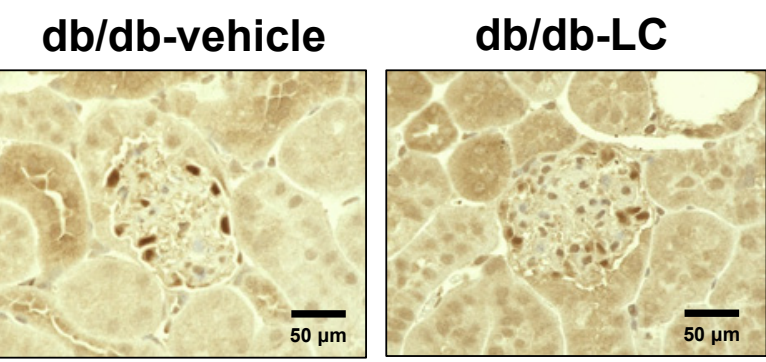

(e)
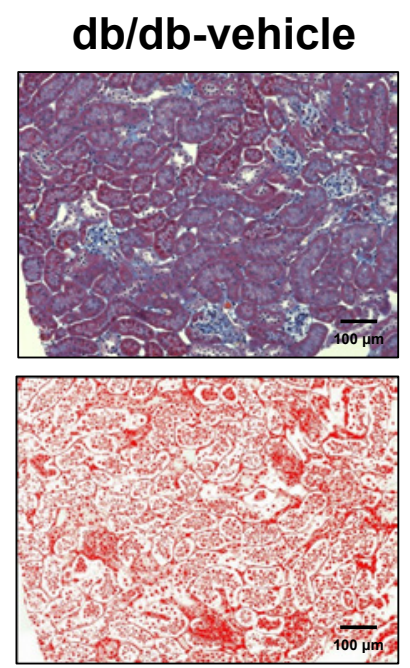

(b)

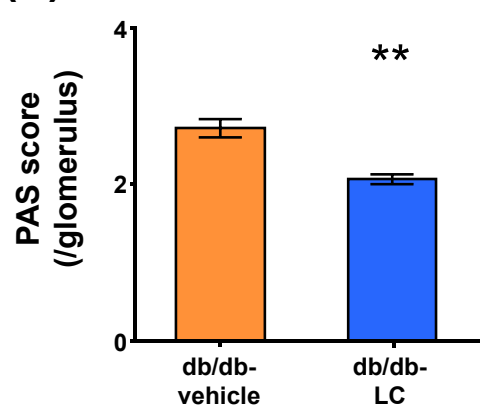

(d)

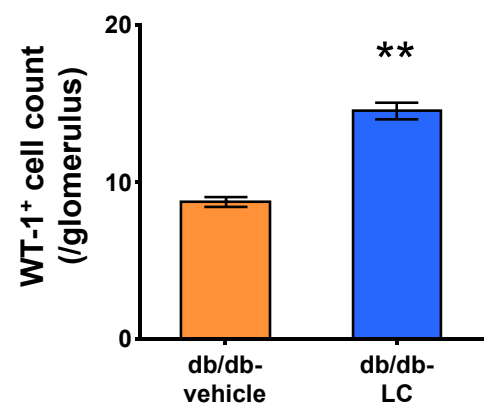

(f)

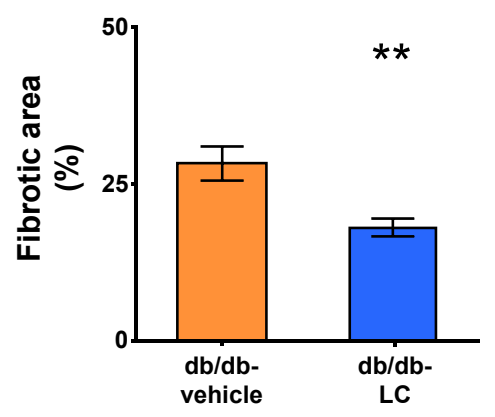

Fig. 4. Effects of L-carnitine on kidney pathology in DN. a Kidney sections were PAS-stained for scoring glomeruli at $\times 160$ magnification. b PAS scores were compared between the $\mathrm{db} / \mathrm{db}$-vehicle and the $\mathrm{db} / \mathrm{db}$-LC mice ( $n=8$ per group). $\mathbf{c}$ Immunohistochemical staining to identify WT- $1^{+}$cells. $\mathbf{d}$ Number of WT- $1^{+}$cells/glomerulus compared between the $\mathrm{db} / \mathrm{db}$-vehicle and the $\mathrm{db} / \mathrm{db}-\mathrm{LC}$ mice ( $n=8$ per group). e Fibrotic areas were identified in Masson tri- chrome-stained sections at $\times 20$ magnification (upper panels) and viewed using ImageJ-Fiji. $\mathbf{f}$ Percentage of fibrotic areas compared between the $\mathrm{db} / \mathrm{db}$-vehicle and the $\mathrm{db} / \mathrm{db}$-LC mice $(n=8$ per group). Data are presented as means \pm standard errors. Comparisons were conducted using the nonparametric Mann-Whitney $U$ test. ${ }^{* *} p<0.01$ versus the $\mathrm{db} / \mathrm{db}$-vehicle mice. 
proximal tubular cells than in misty-vehicle mice $(p<$ $0.01)$. The addition of L-carnitine (db/db-LC) significantly lowered the percentage compared with that in the $\mathrm{db} /$ $\mathrm{db}$-vehicle ( $p<0.01$; Fig. $1 \mathrm{c})$. We also found that the $\mathrm{db} /$ $\mathrm{db}$-LC mice had lesser mitochondrial swelling and cristae loss than the $\mathrm{db} / \mathrm{db}$-vehicle mice in proximal tubular cells (Fig. 1d, e).

\section{Effect of L-Carnitine Treatment on Kidney SOD2}

Expression

SOD2 expression in kidney tissue was significantly lower in $\mathrm{db} / \mathrm{db}$-vehicle mice than in misty-vehicle mice $(p<0.01)$ and significantly higher in $\mathrm{db} / \mathrm{db}$-LC mice than in $\mathrm{db} / \mathrm{db}$-vehicle mice $(p<0.01$; Fig. $2 \mathrm{a}, \mathrm{b})$.

\section{Effects of L-Carnitine Treatment on Serum mtDNA,}

\section{Albuminuria, and Inflammation}

Serum mtDNA was significantly higher in the $\mathrm{db} / \mathrm{db}$ vehicle mice than in the misty-vehicle mice $(p<0.01)$ and significantly lower in the $\mathrm{db} / \mathrm{db}$-LC mice than in the $\mathrm{db} /$ db-vehicle mice ( $p<0.05$; Fig. 3a). The db/db-LC mice excreted significantly less urinary Alb than the $\mathrm{db} / \mathrm{db}$-vehicle mice ( $p<0.01$; Fig. $3 b)$, but the two groups did not differ in serum creatinine levels (data not shown). The $\mathrm{db} / \mathrm{db}$-LC mice also had a significantly lower kidney weight $(p<0.01)$ and number of kidney-infiltrating leukocytes $\left(\mathrm{CD}_{4} 5^{+}\right.$cells; $\left.p<0.01\right)$ than the $\mathrm{db} / \mathrm{db}$-vehicle mice (Fig. $3 c, d$ ). These results suggest that L-carnitine administration mitigated DN-induced inflammatory kidney enlargement. We observed no difference in body weight or blood sugar between vehicle and L-carnitine groups (Fig. 3e, f). The two groups of mice had similar food intake (data not shown).

\section{Effects of L-Carnitine Treatment on Kidney Pathology} in DN

The PAS-stained sections from $\mathrm{db} / \mathrm{db}$-LC mice showed reduced mesangial cell proliferation, alleviated glomerulosclerosis (Fig. 4a), and significantly lower glomerular PAS scores $(p<0.01$; Fig. 4 b). Furthermore, this group had significantly more glomerular WT- $1^{+}$cells (podocytes) ( $p<0.01$; Fig. $4 c, d$ ). Masson trichrome-stained sections revealed that $\mathrm{db} / \mathrm{db}$-LC mice exhibited significantly less kidney fibrosis ( $p<0.01$; Fig. 4 e, f).

\section{Effects of L-Carnitine Treatment on the Proportion and Function of Kidney M $\varphi$ s in DN}

The $\mathrm{db} / \mathrm{db}$-LC mice had fewer CD11b $\mathrm{b}^{\text {high }} \mathrm{M} \varphi$ s and more $\mathrm{CD} 11 \mathrm{~b}^{\text {low }} \mathrm{M} \varphi$ s than the $\mathrm{db} / \mathrm{db}$-vehicle mice (Fig. 5a). Infiltration of both $M \varphi$ types to the kidney was significantly lower in $\mathrm{db} / \mathrm{db}$-LC mice than in $\mathrm{db} / \mathrm{db}$-vehicle mice ( $p<0.05$; Fig. $5 b, c)$. The former group also had a significantly lower CD $11 b^{\text {high }} / C D 11 b^{\text {low }}$ ratio $(p<0.01$; Fig. 5d).

Effects of L-Carnitine Treatment on TLR9, TNF- $\alpha$, ROS, and Phagocytosis in Kidney M $\varphi s$

TLR9 expression in CD11b ${ }^{\text {high }} \mathrm{M} \varphi$ s was significantly higher in $\mathrm{db} / \mathrm{db}$-vehicle mice than in misty-vehicle mice $(p<0.01)$ and significantly lower in db/db-LC mice than in $\mathrm{db} / \mathrm{db}$-vehicle mice $(p<0.01)$, whereas it did not differ between misty-vehicle mice and misty-LC mice (Fig. 6a). TLR9 expression in CD11b ${ }^{\text {low }} \mathrm{M} \varphi$ s was higher in $\mathrm{db} / \mathrm{db}$ vehicle mice than in misty-vehicle mice and significantly lower in $\mathrm{db} / \mathrm{db}$-LC mice than in $\mathrm{db} / \mathrm{db}$-vehicle mice $(p<$ 0.01 ; Fig. $6 \mathrm{~b}$ ). TNF- $\alpha$ production in CD $11 b^{\text {high }} \mathrm{M} \varphi s$ was significantly lower in $\mathrm{db} / \mathrm{db}$-LC mice than in $\mathrm{db} / \mathrm{db}$-vehicle mice (Fig. 6c). Additionally, homogenized kidney tissue from $\mathrm{db} / \mathrm{db}$-vehicle mice had a significantly higher TNF- $\alpha$ content than that from misty-vehicle mice $(p<$ 0.05 ) and the tissue from $\mathrm{db} / \mathrm{db}$-LC mice had a significantly lower TNF- $\alpha$ content than that from $\mathrm{db} / \mathrm{db}$-vehicle mice ( $p<0.01$; Fig. $6 \mathrm{~d}$ ). The percentage of ROS-producing cells in CD11b $\mathrm{b}^{\text {low }} \mathrm{M} \varphi$ s was significantly higher in $\mathrm{db} /$ $\mathrm{db}$-vehicle than in misty-vehicle $(p<0.01)$ and significantly lower in $\mathrm{db} / \mathrm{db}$-LC than in $\mathrm{db} / \mathrm{db}$-vehicle mice $(p<$ 0.01 ; Fig. 6e). However, the percentage of phagocytic cells in CD $11 b^{\text {low }} \mathrm{M} \varphi s$ was higher in $\mathrm{db} / \mathrm{db}-\mathrm{LC}$ than in $\mathrm{db} / \mathrm{db}$ vehicle mice ( $p<0.01$; Fig. $6 f)$.

\section{Discussion}

In this study, we showed that (1) 8-week oral treatment with L-carnitine restored SOD2 and reduced mtROS levels in $\mathrm{CD} 11 \mathrm{~b}^{\text {high }} \mathrm{M} \varphi$ s in proximal tubule cells and circulating $\mathrm{mtDNA}$ of $\mathrm{db} / \mathrm{db}$ mice; (2) this drug downregulated the expression of TLR9 in M $\varphi$ s, thereby reducing the TNF- $\alpha$ level and ROS release; and (3) these effects reduced the infiltration of $\mathrm{CD} 11 \mathrm{~b}^{\text {high }} \mathrm{M} \varphi$ s into the kidney and restored the morphology of glomeruli, tubules, and the interstitium, while decreasing albuminuria in diabetic mice. We thus successfully demonstrated that L-carnitine administration alleviated $\mathrm{DN}$ in an obesity-induced type 2 diabetes mouse model.

Prior to L-carnitine treatment, we confirmed that mitochondrial dysfunction upregulated mtROS production in the kidneys of $\mathrm{db} / \mathrm{db}$ mice, specifically in proximal tubular cells and CD11b ${ }^{\text {low }} \mathrm{M} \varphi$ s. These results suggest that $\mathrm{CD} 11 \mathrm{~b}^{\text {low }} \mathrm{M} \varphi s$ are more similar to tissue-specific cells, 
(a)

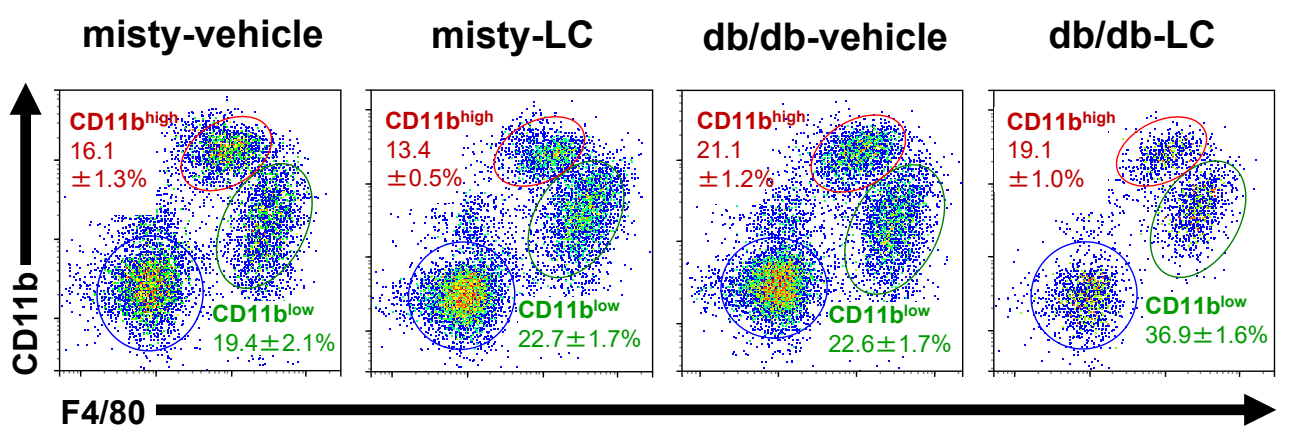

(b)

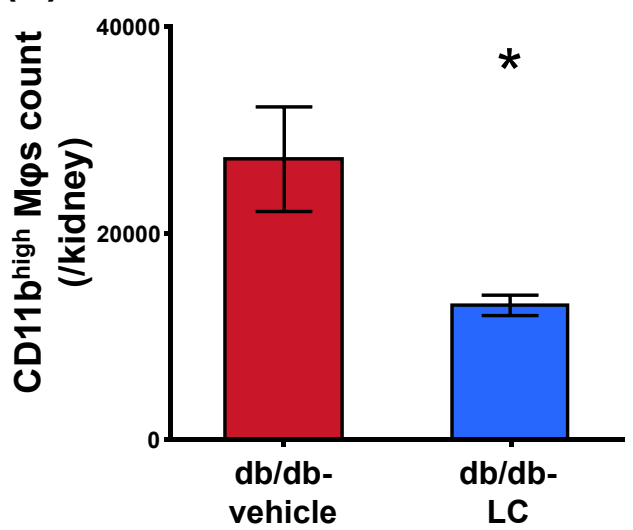

(d)

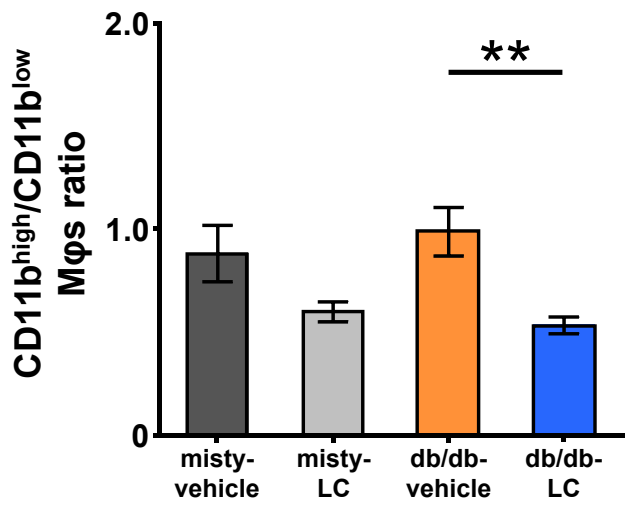

(c)

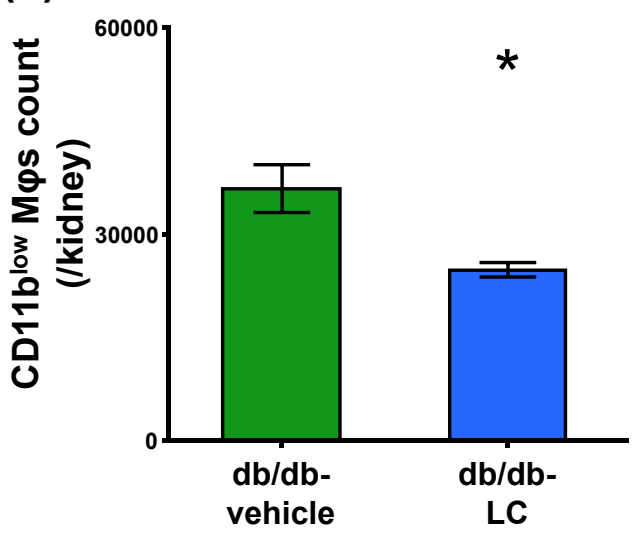

Fig. 5. Effects of L-carnitine on proportion of kidney $\mathrm{M} \varphi s$ in $\mathrm{DN}$. a Distributions of $\mathrm{CD} 11 \mathrm{~b}^{\text {high }} \mathrm{M} \varphi$ s and $\mathrm{CD} 11 b^{\text {low }} \mathrm{M} \varphi$ s were analyzed using fluorescence-activated cell sorting in the vehicle and the LC groups of misty and $\mathrm{db} / \mathrm{db}$ mice $(n=4,4,8$, and 12 , respectively). b Number of kidney CD11b $\mathrm{b}^{\text {high }} \mathrm{M} \varphi \mathrm{s}$ in the $\mathrm{db} / \mathrm{db}$-vehicle and the $\mathrm{db} / \mathrm{db}-\mathrm{LC}$ mice ( $n=8$ and 12 , respectively). Comparisons were conducted using the nonparametric Mann-Whitney $U$ test. ${ }^{*} p<0.05$ versus the $\mathrm{db} / \mathrm{db}$-vehicle mice. c Number of kidney CD-
$11 b^{\text {low }} \mathrm{M} \varphi$ s in the $\mathrm{db} / \mathrm{db}$-vehicle and the $\mathrm{db} / \mathrm{db}$-LC mice $(n=8$ and 12 , respectively). Comparisons were conducted using the nonparametric Mann-Whitney $\mathrm{U}$ test. ${ }^{*} p<0.05$ versus the $\mathrm{db} / \mathrm{db}$-vehicle mice. d Ratio of CD $11 b^{\text {high }} / \mathrm{CD} 11 b^{\text {low }} \operatorname{M\varphi s}(n=4,4,8$, and 12 , respectively). Data are presented as means \pm standard errors. Comparison between groups was performed using one-way analysis of variance with Tukey's HSD post hoc test. ${ }^{* *} p<0.01$. 
(a)

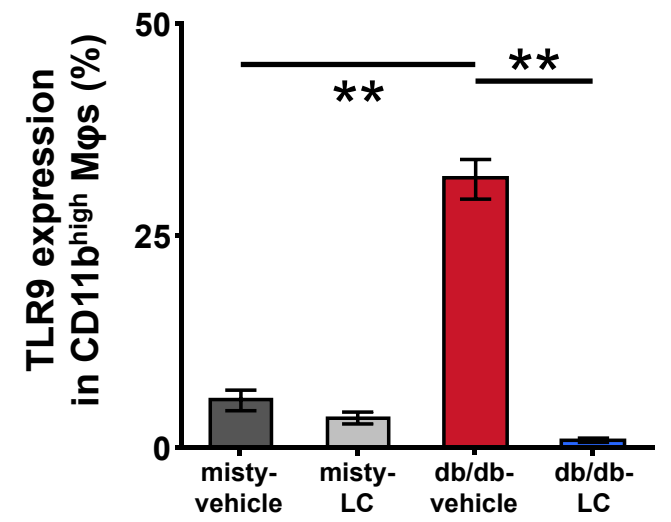

(c)

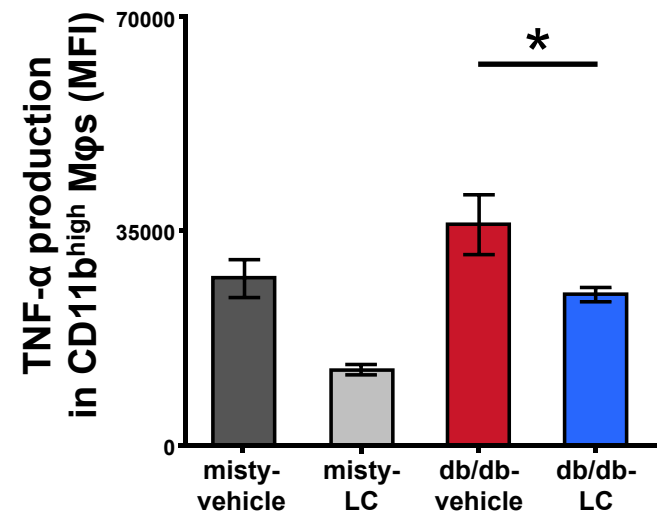

(e)

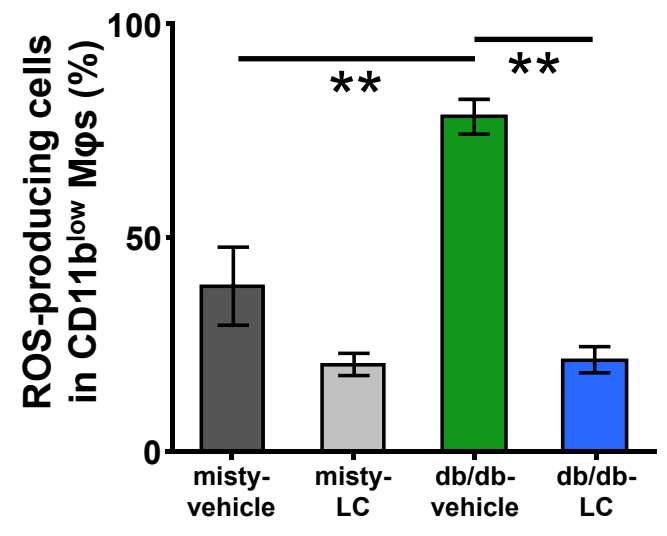

(b)

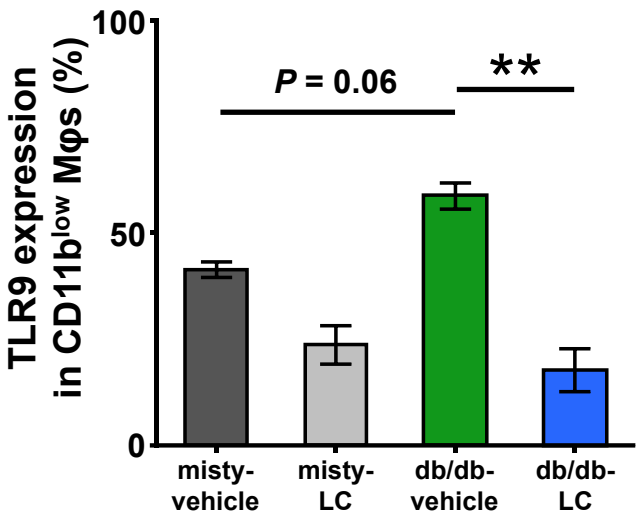

(d)

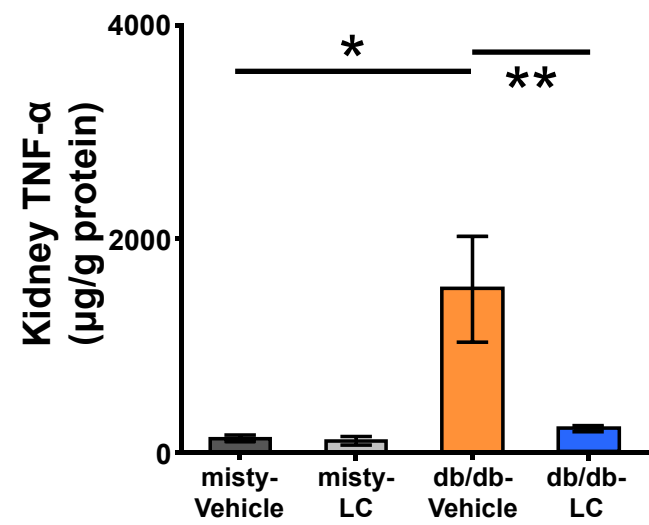

(f)

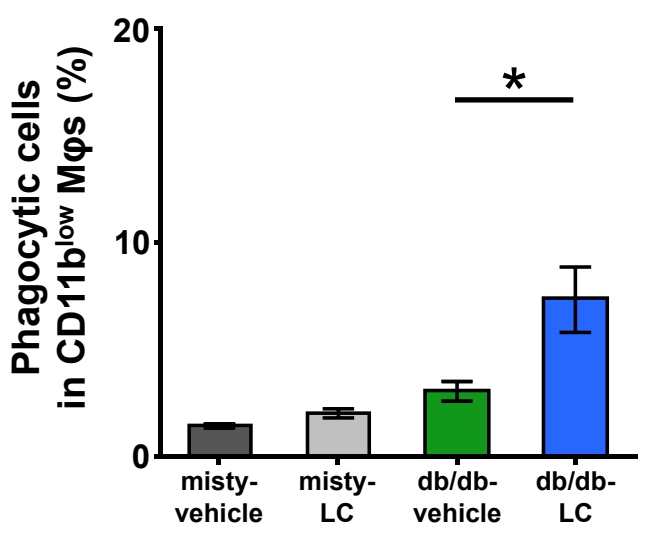

Fig. 6. Effects of L-carnitine on the functions of kidney $\mathrm{M} \varphi s$ in $\mathrm{DN}$. TLR9 expression in CD11 bigh $\mathrm{M} \varphi \mathrm{s}(\mathbf{a})$ and CD $11 b^{\text {low }} \mathrm{M} \varphi \mathrm{s}(\mathbf{b})$, as well as TLR9-induced TNF- $\alpha$ production, in CD11 $\mathrm{b}^{\text {high }} \mathrm{M} \varphi \mathrm{s}$ compared among the vehicle and the LC groups of misty and $\mathrm{db} / \mathrm{db}$ mice (c) $(n=4,4,8$, and 8 , respectively). d TNF- $\alpha$ content in kidney tissue homogenate compared among the vehicle and the LC groups of misty and $\mathrm{db} / \mathrm{db}$ mice $(n=4,4,6$, and 8 , respectively). e Percentage of ROS-producing cells in CD11b ${ }^{\text {low }} \mathrm{M} \varphi s$ among the vehicle and the LC groups of misty and $\mathrm{db} / \mathrm{db}$ mice $(n=4,4,7$, and 8 , respectively). $\mathbf{f}$ Percentage of phagocytic cells in CD $11 b^{\text {low }} \mathrm{M} \varphi$ s compared among the vehicle and the LC groups of misty and $\mathrm{db} / \mathrm{db}$ mice $(n=4,4,6$, and 8 , respectively). Data are presented as means \pm standard errors. Comparison between groups was performed using one-way analysis of variance with Tukey's HSD post hoc test. ${ }^{*} p<0.05,{ }^{* *} p<0.01$. 


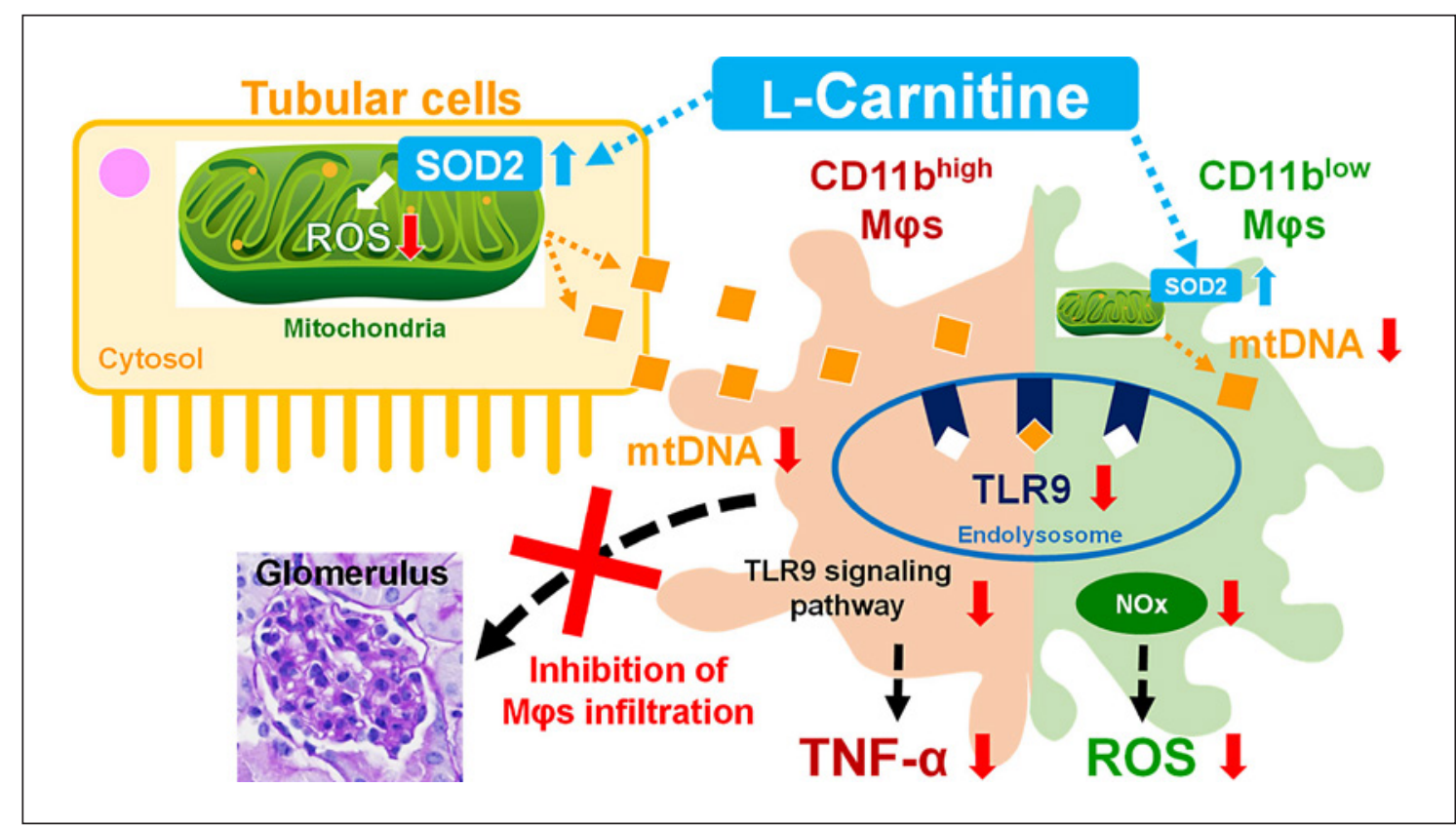

Fig. 7. Schematic representation of the effects of L-carnitine on kidney M $\varphi s$. L-Carnitine administration restores SOD2 levels in the mitochondria of proximal tubular cells and $\mathrm{CD}_{11 \mathrm{~b}}{ }^{\text {low }} \mathrm{M} \varphi s$, which alleviates mitochondrial damage and suppresses mtDNA efflux, thereby inhibiting TLR9 levels in kidney M $\varphi$ s and decreasing their TNF- $\alpha$ and ROS production. Through these mechanisms, L-carnitine contributes to morphological and functional improvements, along with decreased albuminuria, in $d b / d b$ mice. such as proximal tubular cells, than they are to CD $11 b^{\text {high }}$ $\mathrm{M} \varphi s$. In support of this hypothesis, we previously showed that $\mathrm{CD} 11 \mathrm{~b}^{\text {high }} \mathrm{M} \varphi \mathrm{s}$ are derived from the bone marrow, whereas $\mathrm{CD} 11 \mathrm{~b}^{\text {low }} \mathrm{M} \varphi$ s are tissue-resident in the liver [21-25].

Several studies have reported that SOD2 is downregulated in $\mathrm{DN}$ [6-8], and L-carnitine treatment restores its expression [29-32]. Here, we demonstrated that L-carnitine administration increased SOD2 expression in the kidney proximal tubules, coupled with decreasing mtROS production and improving mitochondrial morphology in proximal tubular cells. We therefore postulate that the protective effect of $\mathrm{L}$-carnitine on the mitochondria is exerted through the restoration of mitochondrial SOD2 expression. The increased circulating mtDNA level in $\mathrm{db} /$ $\mathrm{db}$ mice was decreased by L-carnitine administration, suggesting that mitochondrial protection by L-carnitine reduced the amount of mtDNA flowing out from cells such as kidney tubular cells. L-Carnitine also reduced urinary Alb excretion and leukocyte infiltration in the kidney; alleviated inflammatory hepatic swelling, glomerular mesangial proliferation, and interstitial fibrosis; and restored podocyte levels.

Administration of L-carnitine decreased the populations of both kidney CD $11 b^{\text {high }}$ and CD $11 b^{\text {low }} \mathrm{M} \varphi$ s. Par- ticularly remarkable was the inhibition of CD11b ${ }^{\text {high }} \mathrm{M} \varphi$ infiltration into kidneys. L-Carnitine also downregulated TLR9 expression in both types of $\mathrm{M} \varphi s$ after $\mathrm{DN}$-induced upregulation. Moreover, TNF- $\alpha$ production and levels decreased in CD11b $b^{\text {high }} \mathrm{M} \varphi$ s and the kidney tissue homogenate, respectively.

As a further indication of its protective effect, L-carnitine reduced ROS production in CD $11 b^{\text {low }} M \varphi s$. TNF- $\alpha$ and ROS production from CD $11 b^{\text {high }}$ and CD $11 b^{\text {low }} \mathrm{M} \varphi s$, respectively, exacerbates DN symptoms [15-18]. ROS production by $\mathrm{M} \varphi s$ is essential for maintaining homeostasis, but excess ROS causes inflammation and further tissue damage. M $\varphi s$ produce ROS during phagocytosis and digestion of damaged tissue; thus, it is mandatory for maintaining homeostasis. We hypothesize that the mechanisms underlying the protective effects of L-carnitine and DN alleviation begin with restoring SOD2 expression, followed by inhibiting mtDNA efflux, suppressing TLR9, and inactivating kidney M $\varphi$ s.

To further understand the underlying mechanisms of L-carnitine action, we focused on the relationship between glomeruli and tubules. In general, DN increases urinary Alb excretion through two routes: an abnormal slit membrane between foot processes of glomerular podocytes, causing Alb leakage, and impaired Alb reab- 
sorption by tubules. Therefore, as depicted in Figure 7, L-carnitine may have corrected mitochondrial dysfunction in proximal tubule cells, thus suppressing tubule-derived mtDNA efflux. This then inhibited TLR9-mediated activation in kidney $\mathrm{M} \varphi$ s, stopping $\mathrm{CD} 11 \mathrm{~b}^{\text {high }} \mathrm{M} \varphi$ infiltration into glomeruli and $M \varphi$ production of TNF- $\alpha /$ ROS. Additionally, improved tubular function under Lcarnitine treatment restores the Alb reabsorption capacity.

Elevated SOD2 levels, along with lower mtDNA and TLR9 levels, decrease the levels of CD11 ${ }^{\text {low }} \mathrm{M} \varphi$-derived ROS [47]. L-Carnitine enhances the CD $11 b^{\text {low }} \mathrm{M} \varphi$ phagocytic ability by decreasing mtROS levels in CD $11 b^{\text {low }} \mathrm{M} \varphi s$ and proximal tubular cells. This heightened phagocytosis may help prevent infection, repair damaged tissues, and alleviate nephropathy.

L-Carnitine binds to acyl-CoA that is converted from fatty acids, becomes a carrier for acyl-CoA (this binding complex is called acylcarnitine), and helps acyl-CoA to enter the inner mitochondrial membrane and undergo $\beta$-oxidation. In addition, it has been reported that administration of carnitine increases $\beta$-oxidation-related gene expression [48]. Therefore, carnitine presumably promotes $\beta$-oxidation in the proximal tubules of mice. Since excessive acyl-CoA is toxic to the mitochondria, carnitine, which potentiates the metabolism of $\beta$-oxidation, is thought to have a protective effect on the mitochondria $[49,50]$.

We did not clarify whether mitochondrial dysfunction occurs in diabetic $\mathrm{M} \varphi$ s or determine whether L-carnitine has a direct effect on $\mathrm{M} \varphi$ s. However, an increased population of mtROS + cells may reflect mitochondrial dysfunction (Fig. 1), which causes mtDNA leakage into the cytoplasm, upregulating the TLR9-MyD88 pathway [51]. Therefore, we speculate that systemic L-carnitine administration improved mitochondrial function in $M \varphi s$ and suppressed $\mathrm{mtDNA}$ leakage, thereby also inhibiting TLR9 expression.

In large-scale clinical trials of patients with $\mathrm{DN}$, glycemic control suppressed early DN onset and progression to overt DN $[52,53]$. However, DN progression cannot be slowed once the disease becomes overt, even with current therapeutic measures, such as blood glucose treatment, blood pressure control, and renin-angiotensin-aldosterone inhibitors [54]. Moreover, sodium glucose cotransporter 2 inhibitors are associated with improved cardiac metabolism and cardiac ATP production by reducing myocardial mtDNA damage and stimulating mitochondrial biosynthesis [55] and may be useful for kidney mitochondrial protection. Thus, for advanced-stage
$\mathrm{DN}$, it is necessary to develop a therapy that targets the disease mechanism. Inhibition of $\mathrm{M} \varphi$ infiltration into the kidney and regulation of its function through mitochondrial protection in the kidney are considered to be therapeutic methods that can be safely incorporated into existing therapies.

Our study had several limitations. First, although an increased level of circulating mtDNA was confirmed in DN mice, the mtDNA level in the kidney microcirculation was not investigated. However, in this study, since blood was collected in the inferior vena cava near the confluence of the kidney veins, it may reflect an increase in the mtDNA level in the kidney. Second, the direct relationship between changes in TLR9 expression and the amount of mtDNA was not investigated. Previous studies have shown that mtDNA can stimulate TLR9 and that increased cell-free DNA, which may include mtDNA, is associated with increased TLR9 expression $[10,13]$, but it is unclear whether mtDNA directly increases TLR9 expression in M $\varphi s$. It is considered that the decrease in TLR9 expression associated with L-carnitine administration reduced the chance of TLR9 stimulation by mtDNA and contributed to the alleviation of DN, but the decrease in TLR9 expression itself probably occurred independently of mtDNA.

In summary, L-carnitine treatment restored SOD2 and decreased mtDNA levels in proximal tubule cells and $\mathrm{M} \varphi s$ of $\mathrm{db} / \mathrm{db}$ mice. Additionally, it downregulated TLR9 levels in M $\varphi$ s, thereby dampening TNF- $\alpha$ levels and ROS release. These effects restored the morphology of the glomeruli and interstitium while decreasing albuminuria. As $\mathrm{L}$-carnitine is safe for clinical use, we recommend it as a novel therapeutic agent against DN.

\section{Acknowledgments}

We thank Professor Masashi Tsunoda (Department of Preventive Medicine and Public Health, National Defense Medical College) for his kind support. We also thank our colleagues Keiko Komoda, Midori Noguchi, Midori Sano, and Mie Shirase for their expert secretarial assistance.

\section{Statement of Ethics}

All animal experimental protocols were conducted in accordance with the National Institutes of Health Guide for the Care and Use of Laboratory Animals. All protocols were approved by the Animal Ethics Committee of the National Defense Medical College, Japan (approval number: 19004). 


\section{Conflict of Interest Statement}

The authors have no conflicts of interest to declare.

\section{Funding Sources}

This work was supported by grants from the National Defense Medical College to our department.

\section{Author Contributions}

S.I., M.N., and T.I. designed and performed the experiments under the supervision of S.S. and N.O. The manuscript was written by S.I., M.N., T.I., H.N., A.Y., T.I., M.K., S.S., H.K., and N.O. with the final version approved by all the authors.

\section{Data Availability Statement}

All data generated or analyzed during this study are included in this article. Further inquiries can be directed to the corresponding author.

\section{References}

1 Alicic RZ, Rooney MT, Tuttle KR. Diabetic kidney disease: challenges, progress, and possibilities. Clin J Am Soc Nephrol. 2017 Dec; 12(12):2032-45.

2 Qi C, Mao X, Zhang Z, Wu H. Classification and differential diagnosis of diabetic nephropathy. J Diabetes Res. 2017;2017: 8637138.

3 Sourris KC, Harcourt BE, Tang PH, Morley AL, Huynh K, Penfold SA, et al. Ubiquinone (coenzyme Q10) prevents renal mitochondrial dysfunction in an experimental model of type 2 diabetes. Free Radic Biol Med. 2012 Feb;52(3):716-23.

4 Forbes JM, Thorburn DR. Mitochondrial dysfunction in diabetic kidney disease. Nat Rev Nephrol. 2018 May; 14(5):291-312.

5 Melov S, Coskun P, Patel M, Tuinstra R, Cottrell B, Jun AS, et al. Mitochondrial disease in superoxide dismutase 2 mutant mice. Proc Natl Acad Sci U S A. 1999 Feb;96(3):846-51.

6 Kitada M, Kume S, Imaizumi N, Koya D. Resveratrol improves oxidative stress and protects against diabetic nephropathy through normalization of Mn-SOD dysfunction in AMPK/SIRT1-independent pathway. Diabetes. 2011 Feb;60(2):634-43.

7 Park Y, Kim H, Park L, Min D, Park J, Choi S, et al. Effective delivery of endogenous antioxidants ameliorates diabetic nephropathy. PLoS One. 2015;10(6):e0130815.

8 Konari N, Nagaishi K, Kikuchi S, Fujimiya M. Mitochondria transfer from mesenchymal stem cells structurally and functionally repairs renal proximal tubular epithelial cells in diabetic nephropathy in vivo. Sci Rep. 2019 Mar 26;9(1):5184

9 Szeto HH, Liu S, Soong Y, Alam N, Prusky GT, Seshan SV. Protection of mitochondria prevents high-fat diet-induced glomerulopathy and proximal tubular injury. Kidney Int. 2016 Nov;90(5):997-1011.

10 Tsuji N, Tsuji T, Ohashi N, Kato A, Fujigaki Y, Yasuda H. Role of mitochondrial DNA in septic AKI via Toll-like receptor 9. J Am Soc Nephrol. 2016 Jul;27(7):2009-20.
11 Hemmi H, Takeuchi O, Kawai T, Kaisho T, Sato S, Sanjo H, et al. A Toll-like receptor recognizes bacterial DNA. Nature. 2000 Dec; 408(6813):740-5.

12 Dalpke AH, Schafer MK, Frey M, Zimmermann S, Tebbe J, Weihe E, et al. Immunostimulatory CpG-DNA activates murine microglia. J Immunol. 2002 May;168(10):485463.

13 Nishimoto S, Fukuda D, Higashikuni Y, Tanaka K, Hirata Y, Murata C, et al. Obesityinduced DNA released from adipocytes stimulates chronic adipose tissue inflammation and insulin resistance. Sci Adv. 2016 Mar; 2(3):e1501332

14 Wang Y, Wang GZ, Rabinovitch PS, Tabas I. Macrophage mitochondrial oxidative stress promotes atherosclerosis and nuclear factor$\kappa \mathrm{B}$-mediated inflammation in macrophages. Circ Res. 2014 Jan;114(3):421-33.

15 Tesch GH. Role of macrophages in complications of type 2 diabetes. Clin Exp Pharmacol Physiol. 2007 Oct;34(10):1016-9.

16 You H, Gao T, Cooper TK, Brian Reeves W, Awad AS. Macrophages directly mediate diabetic renal injury. Am J Physiol Renal Physiol. 2013 Dec;305(12):F1719-27.

17 Awad AS, You H, Gao T, Cooper TK, Nedospasov SA, Vacher J, et al. Macrophage-derived tumor necrosis factor-alpha mediates diabetic renal injury. Kidney Int. 2015 Oct; 88(4):722-33.

18 Hou Y, Shi Y, Han B, Liu X, Qiao X, Qi Y, et al. The antioxidant peptide SS31 prevents oxidative stress, downregulates CD36 and improves renal function in diabetic nephropathy. Nephrol Dial Transplant. 2018 Nov; 33(11):1908-18.

19 Li L, Huang L, Sung SS, Vergis AL, Rosin DL, Rose CE Jr, et al. The chemokine receptors CCR2 and CX3CR1 mediate monocyte/macrophage trafficking in kidney ischemia-reperfusion injury. Kidney Int. 2008 Dec;74(12): 1526-37.
20 Kawakami T, Lichtnekert J, Thompson LJ, Karna P, Bouabe H, Hohl TM, et al. Resident renal mononuclear phagocytes comprise five discrete populations with distinct phenotypes and functions. J Immunol. 2013 Sep;191(6): 3358-72.

21 Nakashima H, Kinoshita M, Nakashima M, Habu Y, Shono S, Uchida T, et al. Superoxide produced by Kupffer cells is an essential effector in concanavalin A-induced hepatitis in mice. Hepatology. 2008 Dec;48(6):1979-88.

22 Kinoshita M, Uchida T, Sato A, Nakashima $\mathrm{M}$, Nakashima H, Shono S, et al. Characterization of two F4/80-positive Kupffer cell subsets by their function and phenotype in mice. J Hepatol. 2010 Nov;53(5):903-10.

23 Ikarashi M, Nakashima H, Kinoshita M, Sato A, Nakashima M, Miyazaki H, et al. Distinct development and functions of resident and recruited liver Kupffer cells/macrophages. J Leukoc Biol. 2013 Dec;94(6):1325-36.

24 Nakashima H, Ogawa Y, Shono S, Kinoshita M, Nakashima M, Sato A, et al. Activation of $\mathrm{CD} 11 \mathrm{~b}+\mathrm{Kupffer}$ cells/macrophages as a common cause for exacerbation of TNF/Fas-ligand-dependent hepatitis in hypercholesterolemic mice. PLoS One. 2013;8(1):e49339.

25 Nakashima H, Nakashima M, Kinoshita M, Ikarashi M, Miyazaki H, Hanaka H, et al. Activation and increase of radio-sensitive $\mathrm{CD} 11 \mathrm{~b}+$ recruited Kupffer cells/macrophages in diet-induced steatohepatitis in FGF5 deficient mice. Sci Rep. 2016 Oct;6:34466.

26 Jin YZ, Wang GF, Wang Q, Zhang XY, Yan B, $\mathrm{Hu}$ WN. Effects of acetaldehyde and L-carnitine on morphology and enzyme activity of myocardial mitochondria in rats. Mol Biol Rep. 2014 Dec;41(12):7923-8.

27 Le Borgne F, Ravaut G, Bernard A, Demarquoy J. L-carnitine protects $\mathrm{C} 2 \mathrm{C} 12$ cells against mitochondrial superoxide overproduction and cell death. World J Biol Chem. 2017 Feb;8(1):86-94.

28 Sadighara M, Joktaji JP, Hajhashemi V, Minaiyan M. Protective effects of coenzyme Q10 and L-carnitine against statin-induced 
pancreatic mitochondrial toxicity in rats. Res Pharm Sci. 2017 Dec;12(6):434-43.

29 Pesce V, Nicassio L, Fracasso F, Musicco C, Cantatore P, Gadaleta MN. Acetyl-L-carnitine activates the peroxisome proliferator-activated receptor- $\gamma$ coactivators PGC-1 $\alpha /$ PGC- $1 \beta$-dependent signaling cascade of mitochondrial biogenesis and decreases the oxidized peroxiredoxins content in old rat liver. Rejuvenation Res. 2012 Apr;15(2):136-9.

30 Nicassio L, Fracasso F, Sirago G, Musicco C, Picca A, Marzetti E, et al. Dietary supplementation with acetyl-L-carnitine counteracts age-related alterations of mitochondrial biogenesis, dynamics and antioxidant defenses in brain of old rats. Exp Gerontol. 2017 Nov;98: 99-109.

31 Vacante F, Senesi P, Montesano A, Frigerio A, Luzi L, Terruzzi I, et al. L-carnitine: an antioxidant remedy for the survival of cardiomyocytes under hyperglycemic condition. J Diabetes Res. 2018;2018:4028297.

32 Montesano A, Senesi P, Vacante F, Mollica G Benedini S, Mariotti M, et al. L-carnitine counteracts in vitro fructose-induced hepatic steatosis through targeting oxidative stress markers. J Endocrinol Invest. 2020 Apr;43(4): 493-503.

33 Fan JP, Kim D, Kawachi H, Ha TS, Han GD. Ameliorating effects of $\mathrm{L}$-carnitine on diabetic podocyte injury. J Med Food. 2010 Dec 13(6):1324-30.

34 Bene J, Hadzsiev K, Melegh B. Role of carnitine and its derivatives in the development and management of type 2 diabetes. Nutr Diabetes. 2018 Mar;8(1):8.

35 Rolim LC, da Silva EM, Flumignan RL, Abreu MM, Dib SA. Acetyl-L-carnitine for the treatment of diabetic peripheral neuropathy. Cochrane Database Syst Rev. 2019 Jun;6(6): CD011265.

36 Kon K, Ikejima K, Morinaga M, Kusama H, Arai K, Aoyama T, et al. L-carnitine prevents metabolic steatohepatitis in obese diabetic KK-Ay mice. Hepatol Res. 2017 Mar;47(3): E44-54.

37 Inui T, Nakashima H, Habu Y, Nakagawa R, Fukasawa M, Kinoshita M, et al. Neutralization of tumor necrosis factor abrogates hepat- ic failure induced by alpha-galactosylceramide without attenuating its antitumor effect in aged mice. J Hepatol. 2005 Oct;43(4): 670-8.

38 Watanabe A, Marumo T, Kawarazaki W, Nishimoto M, Ayuzawa N, Ueda K, et al. Aberrant DNA methylation of pregnane $\mathrm{X}$ receptor underlies metabolic gene alterations in the diabetic kidney. Am J Physiol Renal Physiol. 2018 Apr;314(4):F551-60.

39 Schindelin J, Arganda-Carreras I, Frise E, Kaynig V, Longair M, Pietzsch T, et al. Fiji: an open-source platform for biological-image analysis. Nat Methods. 2012 Jun;9(7):676-82.

40 Hasegawa K, Yasuda T, Shiraishi C, Fujiwara K, Przedborski S, Mochizuki H, et al. Promotion of mitochondrial biogenesis by necdin protects neurons against mitochondrial insults. Nat Commun. 2016 Mar; 7:10943.

41 Ruiz M, Bégou M, Launay N, Ranea-Robles P, Bianchi P, López-Erauskin J, et al. Oxidative stress and mitochondrial dynamics malfunction are linked in Pelizaeus-Merzbacher disease. Brain Pathol. 2018 Sep;28(5):611-30.

42 Pérez MJ, Ivanyuk D, Panagiotakopoulou V, Di Napoli G, Kalb S, Brunetti D, et al. Loss of function of the mitochondrial peptidase PITRM1 induces proteotoxic stress and Alzheimer's disease-like pathology in human cerebral organoids. Mol Psychiatry. 2021 Oct; 26(10):5733-50.

43 Livak KJ, Schmittgen TD. Analysis of relative gene expression data using real-time quantitative PCR and the $2-\Delta \Delta C T$ Method. Methods. 2001 Dec;25(4):402-8.

44 Morris SM Jr, Gao T, Cooper TK, Kepka-Lenhart D, Awad AS. Arginase-2 mediates diabetic renal injury. Diabetes. 2011 Nov;60(11): 3015-22.

45 Seok SJ, Lee ES, Kim GT, Hyun M, Lee JH, Chen S, et al. Blockade of CCL2/CCR2 signalling ameliorates diabetic nephropathy in $\mathrm{db} /$ db mice. Nephrol Dial Transplant. 2013 Jul; 28(7):1700-10

46 You H, Gao T, Raup-Konsavage WM, Cooper TK, Bronson SK, Reeves WB, et al. Podocytespecific chemokine (C-C motif) receptor 2 overexpression mediates diabetic renal injury in mice. Kidney Int. 2017 Mar;91(3):671-82.
47 Mohamed W, Domann E, Chakraborty T, Mannala G, Lips KS, Heiss C, et al. TLR9 mediates $S$. aureus killing inside osteoblasts via induction of oxidative stress. BMC Microbiol. 2016 Oct;16(1):230.

48 Ishikawa H, Takaki A, Tsuzaki R, Yasunaka T, Koike K, Shimomura Y, et al. L-carnitine prevents progression of non-alcoholic steatohepatitis in a mouse model with upregulation of mitochondrial pathway. PLoS One. 2014; 9(7):e100627.

49 Ferreira GC, McKenna MC. L-carnitine and acetyl-L-carnitine roles and neuroprotection in developing brain. Neurochem Res. 2017; 42(6):1661-75.

50 Rau TF, Lu Q, Sharma S, Sun X, Leary G, Beckman ML, et al. Oxygen glucose deprivation in rat hippocampal slice cultures results in alterations in carnitine homeostasis and mitochondrial dysfunction. PLoS One. 2012; 7(9):e40881.

51 Yao X, Carlson D, Sun Y, Ma L, Wolf SE, Minei JP, et al. Mitochondrial ROS induces cardiac inflammation via a pathway through mtDNA damage in a pneumonia-related sepsis model. PLoS One. 2015;10(10):e0139416.

52 Patel A, MacMahon S, Chalmers J, Neal B, Billot L, Woodward M, et al. Intensive blood glucose control and vascular outcomes in patients with type 2 diabetes. N Engl J Med. 2008 Jun;358(24):2560-72.

53 Ismail-Beigi F, Craven T, Banerii MA, Basile J, Calles J, Cohen RM, et al. Effect of intensive treatment of hyperglycaemia on microvascular outcomes in type 2 diabetes: an analysis of the ACCORD randomised trial. Lancet. 2010 Aug;376(9739):419-30.

54 Abdel-Rahman EM, Saadulla L, Reeves WB, Awad AS. Therapeutic modalities in diabetic nephropathy: standard and emerging approaches. J Gen Intern Med. 2012 Apr;27(4): $458-68$.

55 Yurista SR, Silljé HHW, Oberdorf-Maass SU, Schouten EM, Pavez Giani MG, Hillebrands $\mathrm{JL}$, et al. Sodium-glucose co-transporter 2 inhibition with empagliflozin improves cardiac function in non-diabetic rats with left ventricular dysfunction after myocardial infarction. Eur J Heart Fail. 2019 Jul;21(7):862-73. 